\title{
INTRAEMPREENDEDORES E A INOVAÇÃO EM ORGANIZAÇÃO PÚBLICA
}

\author{
Ana Rita Pires Tavares \\ Bacharela em Administração. Centro Universitário Metodista \\ anarptavares@gmail.com \\ Rafael Freitas Barbosa \\ Mestre em Administração. Centro Universitário Metodista \\ rafael.barbosa@ipa.metodista.br
}

\section{RESUMO}

O empreendedorismo possui papel importante no desenvolvimento econômico e social no país, juntamente com a inovação. Através do empreendedor é possível que segmentos sejam criados e/ou transformados em algo melhor, graças à inovação e aos conhecimentos técnicos e pessoais do profissional visionário. Este profissional, denominado de intraempreendedor ou empreendedor colaborativo, está capacitado a desenvolver ações e participar de decisões da empresa, mesmo que indiretamente. No entanto, nas organizações públicas existem limitações, o que não impede a adesão às mudanças que a inovação proporciona e, através do empreendedorismo, essas modificações podem ser alcançadas em conjunto com o empreendedor colaborativo. O presente estudo buscou descrever os efeitos gerados em uma organização pública que caracterizam a atuação de intraempreendedores. Os resultados foram adquiridos através de pesquisa descritiva, de natureza qualitativa, com a realização de entrevistas com cinco gestoras, gravadas e guiadas por roteiros semiestruturados e da observação não participante. As mesmas foram realizadas por amostragem não probabilística por conveniência. A observação não participante foi a técnica utilizada valendo-se do diário de campo, servindo de apoio no registro dos acontecimentos observados. Como resultado, o perfil de empreendedores e intraempreendedores definidos por autores dos referentes assuntos, condizem às características identificadas em empreendedores colaborativos entrevistados, além de suas atuações executadas sendo parcialmente distintas dentro do ambiente público 
burocrático, com normas e diretrizes pouco flexíveis, conforme autores da administração pública. Em instituições públicas, o empreendedor colaborativo está começando a ser percebido, devido às ações que articula no interior deste sistema, mesmo em meio a uma cultura organizacional considerada fechada e de poucas aberturas para a inovação. PALAVRAS-CHAVE: Empreendedorismo. Intraempreendedorismo. Inovação. Administração pública.

\section{INTRAPRENEURS AND INNOVATION IN A PUBLIC ORGANIZATION}

\section{ABSTRACT}

Entrepreneurship, along with innovation, plays an important role in the economic and social development of the country. Significant changes occur in society as well as in organizations. Through entrepreneurial activity, segments are likely to be created and/or transformed into something better thanks to innovation in addition to the technical and personal knowledge of the visionary professional. Such professionals with particularities typical from entrepreneurship, also known as intrapreneurs or collaborative entrepreneurs, are qualified to develop actions and participate in company decisions even if only indirectly. However, in public organizations there are limitations, which does not prevent adherence to the changes that innovation provides and, through entrepreneurship, these modifications can be achieved together with the collaborative entrepreneur. The present study sought to describe the effects generated that characterize the role of intrapreneurs in a public sector organization. Results were obtained from descriptive qualitative research by means of interviews with five managers, recorded and guided by semi-structured scripts, as well as from non-participant observation. Those interviews were performed by non-probabilistic convenience sampling. The non-participant observation was the technique used, relying on the field diary to register the observed events. As a result, the entrepreneur and intrapreneur profiles defined by the reference authors are consistent with the characteristics identified in the collaborative entrepreneurs interviewed, in addition to actions performed by them, partially distinctive within the bureaucratic public environment with rules and regulations not very flexible according to the public administration reference authors. In public institutions the collaborative entrepreneur is just starting to be noticed due to actions that he or she articulates within the system 
even amid an organizational culture deemed as enclosed and with not many opportunities for innovation.

KEYWORDS: Entrepreneurship. Intrapreneurship. Innovation. Public Administration.

\section{INTRODUÇÃO}

Diante de um cenário onde a cada dia mudanças ocorrem em diversos segmentos, no âmbito organizacional, as inovações se fazem presentes e estar preparado para novos formatos e exigências por parte da sociedade é requisito básico para as organizações, tanto públicas quanto privadas. A Revolução Industrial foi o fator crucial no período contemporâneo, compreendendo o final do século XVIII até os dias atuais, difundindo-se entre os diferentes países do mundo, com a apresentação constante de novas técnicas. No Brasil, a inovação, acompanhada pela tecnologia, apresentou diferentes formas de atuação em diversas atividades econômicas, o que, por conseguinte, acarretou no avanço das técnicas de gestão, tornando-se instrumento importante de modernização. Estes avanços, atrelados à inovação, acabam sendo instrumentos importantes de modernização, bem como a exigência ocasionada por conta da concorrência e maior visibilidade impulsiona para a obtenção da vantagem competitiva. Para Santos (2009), a busca por novas estratégias, através da inovação, possui um papel estratégico rumo ao sucesso das empresas.

Para alguns pesquisadores, o empreendedorismo é considerado como um componente propulsor para o crescimento e desenvolvimento econômico e social, podendo considerar que os empreendedores podem estar inseridos em qualquer ramificação, dedicando-se desde o desenvolvimento de negócios até a geração de riquezas pessoais e coletivas. Para Morais (2013), a prática do empreendedorismo deve ser constituída por recursos importantes para a transformação social e por resgate de valores espirituais e humanísticos, pois, desta forma,

ReMas - Revista Metodista de Administração do Sul, v. 2, N. 2, 2017 
a construção do perfil profissional estará mais direcionada aos novos tempos, também chamado de profissional moderno.

No entanto, ser empreendedor é poder modelar a economia sem fazer parte dela. $\mathrm{O}$ empreendedorismo insere-se em qualquer formato de negócio, de grandes organizações, órgãos públicos, até o empreendedor individual. Segundo Drucker (2005), as possíveis causas da eficiência dos empreendimentos estão ligadas às mudanças de valores, atitudes, percepções e, em alguns casos, mudanças demográficas de algumas instituições. No Brasil, sabe-se que as empresas de pequeno e médio porte são propulsoras em geração de empregos, mesmo em meio à atual crise econômica que, por conseguinte, torna-se imprescindível a existência dos empreendedores. Na análise realizada pelo Global Entrepreneurship Monitor (GEM) referente às taxas de empreendedorismo no Brasil, de 2014 a 2015, o Brasil passou do décimo para o oitavo lugar no ranking dos 31 países de economias impulsionadas pela eficiência, com uma taxa de empreendedorismo inicial (TEA) de 17,2\% em 2014 e 21,0\% em 2015.

Devido ao avanço do empreendedorismo, as empresas estão engajadas nas inovações e, principalmente, dando oportunidade para funcionários inseridos dentro das mesmas, que acabou ganhando a nomenclatura de intraempreendedor, ou seja, o colaborador com características empreendedoras capaz de contribuir na busca de parcerias estratégicas para alavancar os lucros ou na inovação na área técnica, reduzindo custos. Também chamado de intraempreendedor, este profissional é capacitado para participar das decisões nas organizações e possui conhecimento e experiência para que as suas ações sejam aceitas por gerentes e gestores da empresa, mesmo que indiretamente. As empresas privadas que aderirem a este formato de valorização de colaboradores devem ater-se à cultura organizacional existente, ou seja, é necessário investir 
num ambiente adepto a estas mudanças. Estes resultados são alcançados com mais rapidez em empresas privadas, no entanto, nas organizações públicas, que dispõem de uma cultura mais fechada e burocrática, os colaboradores são estimulados apenas a executar processos, ficando as conquistas pessoais e profissionais mais distantes. Nas palavras de Feger, Fischer e Nodari (2009), o agente público precisa seguir procedimentos baseados em princípios da administração pública para exercer os elementos e obrigações necessárias à padronização de suas ações. De acordo com o artigo 37, da Constituição Federal, que estabelece a administração pública direta e indireta de todos os Poderes da União, dos Estados e Municípios e do Distrito Federal, obedecerá aos princípios da legalidade, impessoalidade, razoabilidade, moralidade, publicidade e eficiência.

Diante das informações supracitadas, o referente trabalho baseou-se na importância que as mudanças oriundas da inovação, através do empreendedorismo e a importância do intraempreendedor em propagar esta revolução. A inovação possibilita facilidades e qualidade de acordo com as exigências do seu público-alvo e com os propósitos da organização. Segundo Santos (2009), as empresas inovam-se devido às pressões por parte das crescentes exigências na geração de valor para os consumidores e da alta concorrência, exigindo, além de investimentos, uma inovação por parte de seus agentes. Na visão de Lima et al. (2014), as organizações precisam se estruturar de forma que estas inovações sejam bem administradas, primeiramente dentro das empresas, medindo o nível de desempenho, o planejamento, bem como as suas deficiências, para assim poder destacar seus serviços/produtos frente à concorrência. Além de contribuir para o desenvolvimento da sociedade que está cada dia mais inserida nas inovações, e por consequência mais exigente, o reconhecimento do intraempreendedor é fator importante dentro das organizações

ReMas - Revista Metodista de Administração do Sul, v. 2, N. 2, 2017 
públicas, pois ocorre a valorização mútua e, consequentemente, o apreço no ambiente externo da empresa. A Secretaria de Gestão do Ministério do Planejamento, Orçamento e Gestão (BRASIL, 2000) considera que, para haver mudanças na gestão pública, é necessário mudar a cultura gerencial dos órgãos públicos, através da valorização do servidor público. Complementa ainda, que o termo servir o público perdeu a sua essência ao longo dos tempos e resgatar este conceito de forma equilibrada e inovadora está nas mudanças das pessoas que compõem o ambiente público. Desta forma, pode-se observar que a inovação propicia diferentes formas para a organização que almeja mudanças, bem como, estruturar uma cultura organizacional consolidada por normas e diretrizes consideradas de pouco acesso à transformações inovadoras é algo considerado desafiador. Assim, tem-se como questão central da pesquisa: Quais os efeitos gerados da atuação de intraempreendedores em uma organização pública?

O assunto torna-se significativo para determinadas áreas da administração, uma vez que demonstra as possibilidades relacionadas a inovação, agregada ao empreendedorismo e com a valorização do intraempreendedor e as suas contribuições dentro das organizações públicas. Frente a este contexto, os objetivos deste estudo foram: a identificação do perfil comportamental do intraempreendedor de organizações públicas; a verificação e a percepção de intraempreendedores a respeito da gestão pública e por fim, relatar os incentivos e as barreiras à inovação e ao empreendedorismo dentro da gestão pública, na visão de intraempreendedores. A descrição dos efeitos gerados que caracterizam a atuação de intraempreendedores em uma organização pública, fora o objetivo central da referente pesquisa, com o intuito de apresentar os resultados alcançados com as ações do empreendedor corporativo para instituição governamental. No entanto, as inovações podem ser 
provenientes do empreendedorismo, que pode, por sua vez, ser aproveitado na gestão pública. Para Fontes (2014) o empreendedorismo tem disponibilizado a criação de um conceito real, apto para se inserir na realidade das instituições públicas. Para a autora, este é um modelo de gestão que, elaborado por servidores que almejam oportunidades, possuem capacidade de inovar e, assim, desafiam a gestão atual, instiga uma mudança responsável, além da existência de empreendedores nos serviços públicos.

\section{FUNDAMENTAÇÃO TEÓRICA}

O presente estudo apresenta sua fundamentação teórica baseada nas definições de empreendedorismo e de inovação, bem como o intraempreendedor e o seu papel nas organizações públicas.

\section{As definições do empreendedorismo}

O empreendedorismo visa à construção de algo novo, ou a transformação de algo considerado ultrapassado e sem valor, em produto ou serviço atualizado e com mais aceitação no mercado ou na empresa. Busca entender as oportunidades na criação de novos produtos ou serviços, além de novos mercados, os processos de produção, os formatos de organização referente às tecnologias existentes, bem como descobertas por determinadas pessoas que utilizam vários meios para explorá-las ou desenvolvê-las (BARON; SHANE, 2007). Na visão de Bessi (2016), o empreendedorismo possibilita subsídios para a criação de novos empregos e renda, promove a diversificação da economia local, graças aos novos negócios em variadas áreas. $\mathrm{O}$ envolvimento de pessoas e processos em conjunto, segundo Dornelas (2005), torna possível a transformação de ideias em oportunidades e, quando bem executadas, são levadas à criação de negócios de sucesso. 
Por ser atividade dinâmica e acarretar dúvidas e incertezas, o empreendedorismo é arriscado, segundo Seiffert (2008). O autor salienta que este ofício é complexo por ser influenciado por uma série de fatores econômicos, sociais e institucionais, o que demanda uma combinação perfeita de talentos, ideias e conhecimento. Com o passar dos anos vários autores descreveram sobre o tema, de acordo com o seu entendimento e seguindo a sua especificidade. Sarkar (2008) aborda algumas definições referentes ao empreendedorismo no decorrer dos anos. Segundo ele, autores como Schumpeter, Mc Clelland e Fast trataram o empreendedorismo, no contexto conceitual, como sendo um motivador para a inovação, novos negócios e, por consequência, para o crescimento econômico.

\section{Os tipos de empreendedorismo e o perfil empreendedor}

Procedendo da narrativa de que os economistas foram os primeiros a captar a importância dos empreendedores, apesar de raramente inserirem nos modelos clássicos de desenvolvimento econômico, recentemente começaram a considerar que elementos importantes que compõem o empreendedor são peças-chaves para o desenvolvimento econômico regional (DOLABELA, 2003). Mas, em meio à importância dada pelos economistas ao papel do empreendedorismo na sociedade, comportamentalistas buscavam respostas relacionadas ao perfil do empreendedor. No entanto, diante de várias suposições, acabou-se identificando que não se pode estabelecer um perfil psicológico do empreendedor, uma vez que uma série de variáveis pode influenciar a sua formação. Para Dornelas (2005), a relação do comportamento do empreendedor está ligada ao processo, que se inicia quando há um fato gerador relacionado ao somatório de variados fatores externos, ambientais, sociais e pessoais, possibilitando o início de um novo negócio.

Segundo Dolabela (2003), o perfil do empreendedor será 
diferente em função do tempo, experiência, educação, religião e cultura familiar, bem como, fatores econômicos, faixa etária e o momento atual daquele que resolve empreender. Por isso, não há respostas científicas para descrever o perfil do empreendedor. Já na concepção de Morais (2013), o empreendedor é indivíduo idealista, dinâmico e diligente, tem atitude e corre atrás do seu ideal, faz acontecer, inova e renova. Prioriza a qualidade em tudo que realiza, utilizando os recursos e calculando os riscos que irá correr, possibilitando habilidades propícias para criar equipes de alto desempenho.

De acordo com GEM (Global Entrepreneurship Monitor), os empreendedores são classificados quanto à motivação para a atividade empreendedora, que é subdividida em empreendedor por oportunidade e por necessidade; e através da metodologia de pesquisa, onde os empreendedores são divididos em iniciais e, posteriormente, subdivididos em nascentes e novos, conforme representação da Figura 1, que descreve o processo do empreendedor, segundo GEM.

Figura 1 - Visão ampliada do processo empreendedor segundo definições adotadas pelo GEM

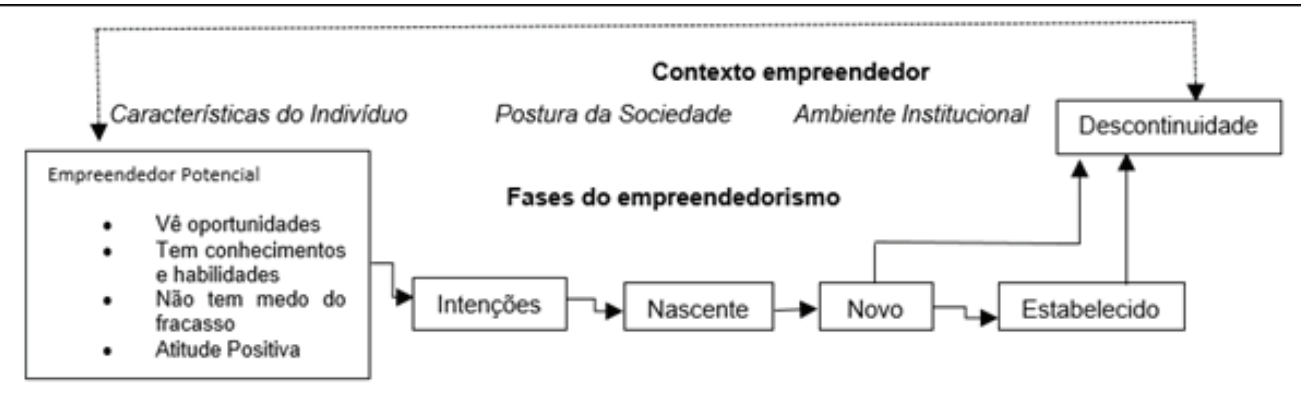

Fonte: Adaptado de Alano et al. (2016, p. 23 apud GEM, 2011).

Os empreendedores nascentes ainda estão envolvidos na parte estrutural do seu próprio negócio, onde não gerou hono- 
rários, pró-labores, ou qualquer tipo de remuneração por mais de três meses. Já os empreendedores novos administram e são donos do seu negócio, rendendo salários, pró-labores, além de outras maneiras de rendimento pelo tempo de três meses e em menos de quatro anos. E, por fim, o empreendedor estabelecido é aquele indivíduo consolidado, ou seja, é proprietário e administra um negócio, gerando ordenados, pró-labores e outras formas de retribuição ao mesmo por mais de 3,5 anos. No entanto, o empreendedor inicial e o estabelecido podem surgir por meio de oportunidade ou por necessidade. Em 2015, uma análise realizada pelo GEM (Global Entrepreneurship Monitor), referente ao empreendedorismo no Brasil, relata a motivação que leva as pessoas a tornarem-se empreendedoras iniciais. Algumas se valem pela oportunidade, onde encontram um nicho de mercado ou uma chance de negócio, mesmo estando empregadas, ou pela necessidade, onde, devido ao desemprego, acabam criando algo com a finalidade de gerar renda para o seu sustento e de suas famílias.

Não é tarefa fácil a identificação da oportunidade. É preciso que o empreendedor esteja atento às possibilidades e aos mecanismos que identificam as oportunidades em potencial, ou seja, aproveitar determinadas situações em que se encontra em busca de uma necessidade e de uma entrada para criar um produto melhor (HISRICH; PETERS; SHEPERD, 2009). No entanto, o empreendedor por necessidade cria seu próprio negócio porque está sem alternativa, variante ao acesso ao mercado de trabalho ou por estar desempregado. Para Dornelas (2007, p. 14), os empreendedores por necessidade "são vítimas do modelo capitalista atual, pois não têm acesso a recursos, à educação e às mínimas condições para empreender de maneira estruturada" e, por consequência, acabam envolvendo-se em negócios informais, executando funções simples e obtendo baixo retorno financeiro. 
De acordo com Bessi (2016), o empreendedor não pensa apenas em ser autônomo e obter lucro com a sua ideia, mas vencer as dificuldades diante do desenvolvimento do negócio, executando os objetivos estipulados durante todo o processo, pois são fatores presentes na consciência do empreendedor. Segundo Maximiano (2011), uma pessoa empreendedora é capaz de idealizar e realizar algo novo, diferenciando-se de outras, que podem ser criativas ou apenas realizarem algo, mas não possuem o talento de criar e realizar juntos.

\section{Intraempreendedor}

A palavra intraempreendedorismo veio do termo intrapreneur, que representa o empreendedor interno, ou seja, o empreendedorismo dentro dos limites de uma empresa já instituída. Segundo alguns autores, a expressão intrapreneur foi utilizada pela primeira vez pelo consultor de administração Gifford Pinchot III, na década de 80. Duas décadas depois, este conceito designa a pessoa que, dentro de organização, assume a responsabilidade direta de transformar uma ideia ou projeto em produto lucrativo através da inovação e de aceitações de riscos. Para Tidd, Bessant e Pavitt (2008), o intraempreendedorismo é usado para descrever as atividades providas pelo empreendedorismo, dentro do cenário corporativo. Já para Hisrich e Peters (2004), o intraempreendedorismo também pode ser chamado de empreendedorismo corporativo, ou seja, ação dos empreendedores dentro das organizações.

Diante da preocupação das empresas em relação à competitividade e o desempenho, a inovação torna-se uma das formas mais contemporâneas de ser alcançada. E um dos fundamentos que estimula para as inovações nas organizações é a ação do empreendedor corporativo (FERRAS et al., 2014). Salientam ainda que, para a inovação ser eficaz dentro da empresa, a cultura deve estar apropriada, pois, do contrário,

ReMas - Revista Metodista de Administração do Sul, v. 2, N. 2, 2017 
dificilmente ela desenvolverá novos produtos e serviços. Lana (2010) enfatiza que a organização que estimula o intraempreendedorismo procura criar condições para que o colaborador se posicione como dono do negócio, construindo uma estrutura e um clima organizacional que apoiem e que permitam o desenvolvimento da inovação.

No entanto, para que o empreendedorismo seja abordado completamente, a inovação, criação e a transformação devem operar de forma conjunta. Lenzi (2008) ressalta que "além disso, quesitos de visão, iniciativa, independência e confiança devem fazer parte deste composto para que haja integração entre os empreendedores corporativos e as respectivas corporações." (LENZI, 2008, p. 6). Para Dornelas (2003), um dos pontos que deve ser trabalhado dentro das organizações é a revelação da inovação em todo o ambiente corporativo, isto é, fazer com que todos os empreendedores compreendam a finalidade da inovação e como ela transcorre.

Lenzi et al. (2012) salienta que o empreendedorismo corporativo está relacionado à inovação e ao benefício que as novas oportunidades podem oferecer, sendo fatores importantes e que devem estar inseridos nos profissionais, independente do tempo vigente da empresa. Por conseguinte, a inovação abrange diversidade e mudança, tanto na tecnologia da empresa em relação a sua organização, quanto ao cenário econômico. Segundo Pavitt, Bessant e Tidd (2008), as empresas passam por desafios quando estão na fase de testes em relação às formas de gerenciar o processo relacionado à solução para o problema da renovação. Para os autores, diferentes circunstâncias podem levar a várias soluções diferentes como, por exemplo, em organizações estatais, que precisam se reconfigurarem com a finalidade de se adaptar às grandes influências externas políticas e reguladoras. 
Ao avaliar o intraempreendedorismo, uma das ligações que se faz é a estrutura organizacional em que se encontra, mas esta lógica não é o bastante. É necessário que se desenvolva um ambiente favorável para o desenvolvimento desta atividade. Processos relacionados à mudança organizacional das empresas acabam se tornando limitadores, ou seja, a resistência em mudar a cultura fortemente enraizada. Shepherd, Peters e Hisrich (2009) ressaltam que o ambiente empreendedor estando propício as organizações devem realizar métodos para a criação. Para os autores, deve haver o comprometimento da alta administração, pois desta forma, a empresa será capaz de efetuar as mudanças culturais necessárias para a inserção do empreendedorismo corporativo. Para Dornelas (2003), seria inútil os esforços por parte das organizações em relação às definições de metas, programas de treinamento, bem como informar aos seus colaboradores sobre a importância do empreendedorismo para o sucesso da empresa se esta peça-chave não faz parte da cultura organizacional.

No entanto, é necessário haver inclusão das práticas do intraempreendedorismo com as diferentes culturas e o parecer tático das organizações em relação ao assunto. Bessi (2016) ressalta a influência que a cultura organizacional recebe conforme as mudanças vão proporcionando ao longo do seu desenvolvimento, por ser considerada uma ferramenta viva. Já para Hisrich e Peters (1992), a estrutura burocrática e a importância nos resultados em curto prazo acabam inibindo a criatividade e o desenvolvimento de novos produtos ou serviços dentro das organizações. Agora, segundo os autores, as empresas estão reconhecendo a importância da inovação dentro das mesmas, dando atenção e mais possibilidades para que a renovação e a criatividade façam parte do cotidiano da organização, estabelecendo o espírito intraempreendedor. 


\section{Inovação}

Originária do latim, innovatio, a inovação refere-se à ideia técnica, pouco parecido com o que já existe. Mas, em termo conceitual, a inovação não é nova, pois acompanha a elaboração da teoria das organizações e os conceitos administrativos (DORNELAS, 2003). A inovação conceitua-se em mudar algo considerado antigo e, dependendo do cenário em que se insere, possui o poder de criar algo novo, ganhando maiores proporções com a chegada da tecnologia e a sua gama de facilidades e novidades. Para Tidd, Bessant e Pavitt (2008) a inovação é instigada pela rapidez no estabelecimento das relações, descobrindo oportunidades e aproveitando-as. Ocupa papel importante na economia, uma vez que contribui com o desenvolvimento econômico junto às empresas e, por conseguinte, para a sociedade em que se insere. Para Souza (2009), "vivenciamos tempos globalizados, onde existem enredos interconectados por computadores conectados a milhares de satélites que processam informações a velocidades fantásticas e indescritíveis." (SOUZA, 2009, p. 76).

E, para entender melhor a importância da inovação e as suas características, a contribuição de Schumpeter, na primeira metade do século $X X$, relata o valor das inovações e dos avanços tecnológicos para o desenvolvimento das organizações e da economia. Considerado o pai dos estudos sobre inovação, o economista Joseph Schumpeter argumenta que os empresários farão uso da inovação tecnológica, ou de um produto/ serviço, com a finalidade de obter benefício estratégico. Para ele, este é um ciclo onde o empresário que observar o crescimento/venda desta inovação irá copiar o feito para alcançar ou ultrapassar o concorrente e a busca pela próxima inovação continuará, o que, por sua vez, irá refazer as regras desta competição (SCHUMPETER, 1950). Para o economista, esta prática ocasiona a destruição criativa, devido à intensa busca 
por algo inovador, o que acaba anulando as antigas regras e estipulando as novas. E complementa que há concorrência entre o que é novo como o consumo, a tecnologia ou novo tipo de organização, não afetando a margem de lucro e os resultados das organizações existentes, mas os seus princípios e suas vidas (SCHUMPETER, 1950).

Para valer-se da inovação dentro de uma empresa, é preciso que o conhecimento e o saber utilizar este artifício seja despertado e aproveitado. De acordo com Jones (2010), a valorização das ideias do colaborador dentro de uma empresa deve ser considerada e reconhecida, podendo ser inserida ou adaptada na cultura organizacional da empresa. Segundo Selman (2010), a atualização das habilidades por conta das empresas e dos indivíduos deve ser contínua, à medida que as mudanças dentro das organizações ocorrem. Segundo o autor, a tecnologia propicia dificuldades e oportunidades que agregam no desenvolvimento dos processos organizacionais. Por conta da junção de estratégia, tecnologia e processos, as empresas têm a necessidade de mudar e se reinventarem constantemente. A inovação pode ser interpretada de algumas maneiras: como sendo algo novo e inédito ou como sendo a reinvenção do invento. Mas o que pode ser observado é que a inovação pode ser considerada como algo plausível, mas de grande velocidade, pois se propaga com muita rapidez e, nos tempos atuais, as empresas devem acompanhar esta aceleração constante. Esta corrida inovadora é chamada de inovação sistemática por Drucker (2005). Segundo o autor, os empreendedores deverão aprender esta prática, pois ela "consiste na busca deliberada e organizada de mudanças, e na análise sistemática das oportunidades que tais mudanças podem oferecer para a inovação econômica ou social." (DRUCKER, 2005, p. 45). 


\section{Cronologia da Inovação}

A criação da inovação é considerada, por alguns autores, desde os primórdios da existência humana, ou seja, quando o homem passou a valer-se de descobertas providas de objetos considerados incomuns e sem utilidades, como maneira de sobreviver em diversas situações. Souza (2009) salienta que a inovação se faz presente desde as manifestações históricas que, segundo a autora, são transparentes há 500.000 anos. Já para Asimov (1993), essas manifestações surgiram desde os antepassados, com a técnica de fazer fogo, invenção da lâmpada a óleo (20.000 a. C), motor rotativo de ação dupla que acaba com o predomínio da tração animal modificando a produção agrícola (8.000 a. C), bem como o adestramento dos bois ou dos cavalos (2.000 a. C), chegando à fissão nuclear no século XX. $\mathrm{O}$ autor lista outros surgimentos que proporcionaram o crescimento do homem e o desenvolvimento de cunho comercial e, por conseguinte, a inovação, de forma sucinta, vai surgindo no decorrer dos tempos. Desta forma, pode-se observar que, com a invenção da máquina, a inovação fez parte de cada passo da história no que se refere ao processo de industrialização, onde a partir de momentos como a Primeira Revolução até a chamada Quarta Revolução Industrial, estão relacionadas a energia a vapor no século XVIII, a energia elétrica no século XIX, a energia nuclear e, por último, a informatização, comunicação e telecomunicação que se expandem pelos séculos $X X$ e XXI, constroem a história mundial.

\section{Tipos de Inovação}

A inovação é envolta de características diferentes que dependem de cada agente e da sua forma em lidar com os novos conhecimentos, bem como de criar e aprender com os mesmos, além das diferentes fontes de inovação e dos ambientes em que se encontram, tal como o grau de entendimento oculto existente nesses locais (ALBAGLI; LASTRES, 1999). 
O que pode ser observado é que a inovação possui várias maneiras de ser incorporada e/ou incrementada na rotina empresarial. Para Mattos et al. (2008), mesmo com a geração de lucro, não inovar pode significar perdas significativas. Salientam que podem existir diversos tipos de inovação nas empresas, como a inovação em produtos (bens ou serviços), que constitui na elaboração de novos produtos ou aprimoramento de produtos já existentes, suprindo as necessidades do mercado. A inovação em processos visa o aperfeiçoamento ou criação de novos formatos de fabricação e/ou distribuição de bens, tal como renovação de prestação de serviços. Há a inovação organizacional, que se vale da aplicação de novos métodos de organização e gestão, tanto no ambiente de trabalho quanto no vínculo da empresa com o mercado, bem como com os fornecedores e/ou distribuidores. E por fim, a inovação em marketing ou modelos de negócio que adere às novas técnicas de marketing e comercialização, com alterações significativas na elaboração do produto, no design, na embalagem, na imagem do produto no mercado, em sua divulgação ou na sua definição de preços. Para Lana (2010, p. 41), a inovação "está no tipo de produto vendido, no design, na forma de comercialização de bens e serviços, no marketing utilizado, no relacionamento e nos serviços prestados aos clientes, na organização e na forma de gestão da organização."

Com relação às diversas nuances em que a inovação insere-se, a sua conexão no mercado pode percorrer caminhos distintos, podendo ser intensas ou não. Essas variações são chamadas de inovação incremental ou radical. Lana (2010) as classifica como:

a) inovação radical - são novos produtos, provenientes de novas ideias. São produtos ou processos que não existiam no mercado anteriormente; 
b) inovação incremental - é quando há melhorias em algo existente, podendo haver um refinamento no modo de fazer, através de novos materiais, desenhos ou embalagens, ou pelo acréscimo de utilidades diferenciadas, tornando os produtos mais atrativos pelos seus clientes e assim acaba sendo mais competitivo.

Já Souza (2009) refere-se à inovação radical como uma quebra de paradigmas, cuja a mudança intensa num produto ou processo envolvido é mais dificultosa citando, como exemplo, a lâmpada elétrica. A mesma visão segue Simantob e Lippi (2003) em relação à inovação radical, em que segundo os autores, a busca contínua pela ruptura e quebra de paradigma faz-se presente neste quesito. Já no que tange à inovação incremental, a busca pelo aperfeiçoamento é constante e gradativa, segundo os autores. Para Monteiro Jr. (2011), a inovação incremental propõe melhorias gradativas num produto, serviço, processo ou prática em algo que já existe, ou seja, estas inovações ao longo do tempo podem ser denominadas de melhorias contínuas. Em relação à inovação radical, o autor a descreve como sendo a inserção de produtos novos, bem como práticas e gestão. E através destes novos produtos e serviços é possível o surgimento de setores ou mercados inéditos.

Por fim, a visão da inovação foi adaptada com sendo algo precursor de bens e serviços novos no mercado, por Rocha Neto (2004). Segundo ele, a inovação radical abrange a tomada de ideias concretizadas em criações ou descobertas de novos recursos existentes na natureza. O autor completa que novos produtos, utilização de novos processos de produção e gestão podem ser mudados de forma radical, apoiados nos conhecimentos aplicados na produção de cada um. Em relação à inovação incremental, o autor ressalta as mudanças incrementadas através da experiência ou por meio da evolução provida da prática diária. No entanto, finaliza esta combinação 
abrangendo uma ampla visão de possibilidades, que inicia no simples aperfeiçoamento de produtos ou processos até os mais requintados usos de conhecimentos técnicos/científicos (ROCHA NETO, 2004).

\section{ADMINISTRAÇÃO PÚBLICA}

Para entender sobre a gestão pública, é necessário saber um pouco da história da administração pública no Brasil e das suas características. Existem três formas de administrar o Estado: a administração patrimonialista, a pública democrática e a pública gerencial, para esclarecer o papel do Estado moderno e suas recentes transformações, reconstruindo os processos de formação e diferenciação histórica da instituição política e do mecanismo organizacional que lhe dá fundamento.

\section{Administração Patrimonialista}

A estrutura política e administrativa no Brasil baseou-se no modelo português com o patrimonialismo, em que havia troca de favores, ou seja, gratificava-se com a distribuição de cargos em pagamento do favor prestado e na afeição que porventura existisse. No entanto, o Estado era a ampliação do poder do administrador público e os seus servidores eram conhecidos como nobres, pois receberam a titulação graças à indicação do governante. Na visão patrimonialista, entendia-se que o Estado deveria ter as suas necessidades supridas pelos seus trabalhadores nomeados, sem se preocupar com o bem-estar social e em suprir as necessidades da sociedade. Posicionava-se como entidade e acabava havendo um grande erro em relação ao que era público e privado. Com a Revolução Francesa, os princípios democráticos acabaram por pressionar para que houvesse uma administração pública mais centrada, atendendo os princípios constitucionais com imparcialidade, moralidade e transparência. Diante deste movimento e ao au-

ReMas - Revista Metodista de Administração do Sul, v. 2, N. 2, 2017 
mento do ponto de vista capitalista, a sociedade e o mercado diferenciaram-se do Estado.

Para Bresser-Pereira (2000), patrimonialismo significa a incompetência ou capricho de o príncipe separar o patrimônio público e seus bens particulares. Na concepção de Amorim (2000), o patrimonialismo acabou dando margem para a corrupção no âmbito estatal:

Suas intenções moralizantes frustraram-se, face ao excessivo formalismo dos controles internos e a falta de transparência dos atos públicos, abrindo espaço para a formação interna de grupos de interesse e para a ampliação dos níveis de corrupção no aparelho estatal. (AMORIM, 2000, p. 96).

Em meio às atitudes apresentadas, a administração patrimonialista é vista como incapaz e intolerável, surgindo assim, o anseio por mudanças.

\section{Administração Pública Burocrática}

A partir do século XIX, a administração patrimonialista passa a ser impraticável devido ao surgimento do capitalismo industrial e das democracias. Para o capitalismo, a união entre o Estado, o mercado e a democracia só poderia existir quando a sociedade se separasse do Estado e, assim, começasse a controlá-lo. Foi, então que houve a necessidade de distinguir o público do privado. Desta forma, a administração burocrática contribuiu para censurar a corrupção e o nepotismo. Sua hierarquia é vertical devido aos vários níveis hierárquicos, sendo que a divisão de trabalho/função é horizontal. Para Bresser-Pereira (2000), a administração pública burocrática está fundamentada no serviço civil profissional, regido pela dominação das regras weberianas e na generalização de sistemas, explícito em normas rígidas pertencentes às atividades administrativas. 
No entanto, Paludo (2013) ressalta que o modelo utilizado nos dias de hoje é a administração gerencial, mas a administração burocrática ainda permanece, ou seja, suas diretrizes são aplicadas no núcleo estratégico do Estado e em organizações públicas, além de existirem as maneiras e práticas adotadas no modelo patrimonialista nos tempos atuais. $\mathrm{O}$ autor ressalta que, atualmente, é possível encontrar elementos de todas as teorias administrativas vigentes nas administrações públicas.

\section{Administração Pública Gerencial}

Após as duas guerras mundiais do século XX, o Estado precisou se refazer e assim passou a ser um Estado Social, onde tinha como dever o acesso da população à moradia, educação, saúde, etc. Diante deste cenário, aumentou o número de pessoas que exerciam as suas atividades, pensamentos neoliberalistas que acabaram sugerindo para que a economia e o mercado criassem suas próprias regras. Silva (2013) cita que a administração pública gerencial tem como objetivo principal aumentar a qualidade dos serviços e reduzir os custos, além de incrementar uma cultura gerencial nas organizações, guiadas para os resultados e com o aumento da governança do Estado, ou seja, com a finalidade de gerenciar com aptidão e competência.

Apesar de ser formada após a administração pública burocrática, a administração pública gerencial possui indícios que levam à associação entre ambas. Este modelo tornou-se real no mundo desenvolvido onde com a objetividade bem definida em cada unidade da administração, da descentralização, da mudança de estruturas organizacionais e da adesão de valores e comportamentos modernos, originárias no interior do Estado, manifestou sua capacidade em aumentar a qualidade e a eficácia dos serviços sociais ofertados pelo setor público (PALUDO, 2013). 
Mesmo com as tentativas do Governo Federal em implantar modelos da administração gerencial no Brasil, as técnicas patrimonialistas ainda permanecem na gestão pública dos estados, municípios e união, não somente nos três poderes: Executivo, Legislativo e Judiciário. A diferença da administração gerencial para a burocrática encontra-se na forma de controlar, ou seja, atém-se nos resultados, nos objetivos desejados. Segundo Torres (2004), o modelo burocrático não foi adotado em sua plenitude no Estado brasileiro, pois permanece sendo administrado por meio de métodos que acabam por desconhecer ou desprezar os princípios da impessoalidade, publicidade, especialização, profissionalismo, entre outros. Amorim (2000) entende que, mesmo em meio ao processo de desenvolvimento capitalista adotado pelo Estado, e por vincular outros atributos ligados ao modelo burocrático e ao gerencial, ele nunca se desfez do antigo modelo patrimonialista e clientelista em que, frente a uma ameaça, propõe-se a renascer com força e com um novo item, o corporativismo.

\section{Abordagem clássica da administração}

Surgindo na primeira metade do século $X X$, a teoria clássica da administração tornou-se o elo administrativo entre a estrutura organizacional e os princípios universais de administração. Teve como fundador o engenheiro europeu Henri Fayol, que desenvolveu esta teoria com a intenção de aumentar a eficiência das empresas através da organização e da utilização dos princípios gerais da administração em bases científicas. Apesar de não obterem relação entre si e terem sido constituídos a partir de visões diferentes, ambas as ideias são base para a Abordagem Clássica da Administração, fazendo parte do quadro administrativo das organizações nas primeiras quatro décadas do século XX (CHIAVENATO, 2003). 
Para Fayol, as empresas constituem-se em seis funções, como: funções técnicas ligadas à produção de bens e serviços; funções comerciais, relacionadas às compras, vendas e trocas; funções financeiras, que agregam a gerência de capitais; funções de segurança, que relacionam a proteção e preservação dos funcionários e dos bens da empresa; funções contábeis, que atuam diretamente com inventários, registros, balanços, custos e estatísticas; funções administrativas, que estão associadas com a junção das outras cinco funções e, assim, coordenam e sincronizam ambas, mantendo-se em nível acima de todas. Em suma, o autor define que o procedimento de administrar resume-se em prever o futuro, organizar constituindo o segundo sistema material e social da empresa, comandar de forma a encaminhar os funcionários, coordenar de maneira harmoniosa e unida todos os esforços coletivos e, por último, controlar para que seja averiguada a execução das tarefas dentro das normas e regras estabelecidas (CHIAVENATO, 2003).

Em contrapartida, em plena era de mudanças e instabilidade, esta abordagem revela-se "rígida, inflexível e conservadora, pois ela foi concebida em uma época de estabilidade e permanência." (CHIAVENATO, 2003, p. 91). O que não significa a sua inutilidade nos dias de hoje, pois a teoria clássica é imprescindível no entendimento das bases da moderna Administração, completa Chiavenato (2003).

\section{Abordagem Estruturalista da Administração}

Também conhecida como a Teoria da Burocracia, surge por volta da década de 1940, onde outras teorias como a Clássica e das Relações Humanas, concorriam entre si o seu lugar na teoria administrativa, mas já mostravam sinais de ultrapassadas para a época. Foi no início do século XX que o sociólogo alemão Max Weber publicou seu livro baseado em estudos relacionados às organizações sob o ponto de vista

ReMas - Revista Metodista de Administração do Sul, v. 2, N. 2, 2017 
estruturalista, ou seja, apresentando a relação entre os meios e os recursos usados para que os objetivos das organizações burocráticas fossem alcançados. Este foi o século em que a burocracia ganhou força devido às necessidades das empresas em se organizarem e das reivindicações por tratamento justo e imparcial por parte dos trabalhadores e, assim, o formato burocrático proliferou-se em todos os tipos de organizações humanas (indústrias, empresas de prestação de serviços, repartições públicas, entre outras). Na visão de Weber, este modelo burocrático adotado pela administração acabou por colocá-la no alto da hierarquia, com o uso de regras claras e impessoais, almejando eficiência. Por conseguinte, acreditou que a burocracia pode fazer a organização eficiente por excelência. $\mathrm{Na}$ visão dos estruturalistas, a sociedade moderna e industrializada é constituída por uma sociedade de organizações, onde as pessoas necessitam das mesmas para sobreviver. Devido ao grau de diferenciação das empresas, os integrantes deveriam possuir características adequadas ao que seriam impostos, ou seja, por haver vários tipos de personalidade em variadas organizações, as atividades a serem desempenhadas também seriam diversificadas, havendo a interação entre si dos grupos sociais e dos grupos das empresas (CHIAVENATO, 2003).

No que tange a diversidade de organizações, trata-se da inclusão de diferentes tipos de organizações além das fábricas, que vão desde empresas de pequeno e médio porte até organizações públicas, religiosas, partidos políticos, etc. No entanto, as organizações nem sempre estão em constante harmonia. Chiavenato (2003) explica que há conflitos e dilemas organizacionais que acabam por provocar apreensão, envolvendo pontos positivos e negativos, mas com a resolução desses aspectos, a organização acaba por ser conduzida à inovação e à mudança. Já para Abrantes (2012), a Teoria Estruturalista contribui para a inserção do componente social em relação 
aos estudos das organizações, considerando a existência de ambientes internos e externos. Para o autor, este componente possibilitou o aumento dos conhecimentos e entendimentos relacionados aos acontecimentos que ocorriam dentro das fábricas, muitas vezes ocultas devido ao sistema imposto que determinava a maneira de agir das pessoas: o meio ambiente, ou seja, com a existência de grupos que determinavam a maneira de agir das pessoas e todos acabam sendo orientados individualmente pelos próprios integrantes. Abrantes (2012) salienta que esta teoria pode ser aplicada em variados tipos de organizações e setores da economia e, assim, "aceita o conflito interorganizacional, especialmente entre pessoas, e afirmando que é da discordância de ideias que surgem inovações, isto como fruto da capacidade criativa do ser humano." (ABRANTES, 2012, p. 133).

\section{METODOLOGIA}

No presente estudo, os objetivos foram caracterizados através de uma pesquisa descritiva, tendo como abordagem do problema a utilização de uma pesquisa qualitativa, onde será descrito o parecer de intraempreendedores de uma universidade federal localizada em Porto Alegre e as barreiras à inovação e ao desenvolvimento do empreendedorismo na instituição pública. Inclui-se, também, a visão dos gestores sobre a implantação desta inovação voltada para este segmento, utilizando, como procedimento, o levantamento de campo.

Para Barros e Lehfeld (2007), na pesquisa com abordagem descritiva o pesquisador apenas descreve o objeto da pesquisa, descobrindo a frequência dos acontecimentos, sua origem, características, causas, vínculos, com outros acontecimentos, sem que haja a interferência do pesquisador. Desta forma, a pesquisa descritiva acarretará hipóteses e informações que necessitarão de detalhamento na sua construção. A pesquisa

ReMas - Revista Metodista de Administração do Sul, v. 2, N. 2, 2017 
com abordagem qualitativa, segundo Mazzotti e Gewandsznajder (2001), não aceita regras claras, aplicável a diversos casos, pois este tipo de pesquisa diferencia-se quanto aos aspectos que podem ser definidos no projeto. Porém, para Flick (2009, p. 96), a pesquisa qualitativa "não pode ser caracterizada pela preferência por determinados métodos em relação a outros."

Quanto aos procedimentos, foi realizado um estudo de caso. Mascarenhas (2012) descreve o estudo de caso como uma reflexão relacionada ao conjunto de informações relatando com ênfase o objeto de estudo através de uma pesquisa mais precisa sobre um ou poucos objetos. Para Farias Filho e Arruda Filho (2013), esta técnica é mais utilizada na elaboração de hipóteses e na reavaliação de problema, mas em sua maioria não concede o aumento dos resultados. Na opinião de Diehl e Tatim (2004), este método oferece vantagens como os incentivos às novas evidências, o destaque no montante das informações e a facilidade da técnica a ser utilizada. No que se refere às desvantagens, os autores citam a dificuldade em desenvolver os resultados atingidos e, por consequência, acaba por exigir do pesquisador maior capacidade em relação aos outros tipos de abordagem.

Já delimitação da pesquisa, para Marconi e Lakatos (2010), possibilita estabelecer limites para a investigação, que pode ser relacionado ao assunto, à extensão e a uma série de fatores, mas nem sempre o uso da delimitação é necessário, uma vez que o assunto estudado e os seus objetivos podem determinar limites. Neste estudo, com a definição da delimitação, a pesquisa foi aplicada em áreas de uma universidade federal que atuam no incentivo e na propagação do empreendedorismo. Foram realizadas entrevistas com cinco gestoras responsáveis pelo empreendedorismo na Instituição, caracterizadas como sujeitos da pesquisa, salientado pelo critério de conveniência. São profissionais, concursadas ou não, que atuam na instituição 
pública objeto da pesquisa, e desenvolvem nestas atividades empreendedoras ou com empreendedores. Executadas no mês de agosto de 2017, nos respectivos locais de trabalhos, as entrevistas iniciaram-se com a Entrevistada A, técnica administrativa do Centro de Empreendimentos de Informática da instituição, formada em Administração e há três anos faz parte da equipe administrativa. Já a Entrevistada 2 foi a coordenadora pedagógica da Secretaria de Desenvolvimento Tecnológico. Formada em Matemática, exerce suas funções há oito anos como colaboradora concursada da Universidade. A Entrevistada 3 foi a assessora de projetos e interação na mesma secretaria supracitada, sendo funcionária pública há 11 anos da instituição. E a Entrevistada 4 foi a vice- coordenadora do Núcleo de Empreendedorismo da Universidade. Formada em Ciências Contábeis e Economia, mestre em Administração e com doutorado na área da inovação, executa suas funções há sete anos como docente concursada da Universidade. E, por último, a Entrevistada 5, chefe de departamento da engenharia de produção da Escola de Engenharia e integrante do Núcleo de Empreendedorismo da Universidade estudada.

A definição de cinco sujeitos da pesquisa e da instituição onde exercem suas atividades profissionais caracteriza-se por ser uma amostra não probabilística, que é descrita por Hair Jr. et al. (2005) como forma que possibilita a captação e seleção de elementos mais disponíveis e necessários, e assim oferece as informações necessárias. Por fim, o desenvolvimento da presente pesquisa valeu-se de entrevista guiada por roteiro semiestruturado e da observação não participante através do instrumento diário de campo. Segundo Barros e Lehfeld (2007), a entrevista é uma técnica que admite um relacionamento mais cordial entre o entrevistado e entrevistador. Na percepção de Flick (2009), esta técnica pode ir um tanto além e assim tornar-se interessante para o planejamento de outras formas de

ReMas - Revista Metodista de Administração do Sul, v. 2, N. 2, 2017 
entrevistas. Suposições podem ser explícitas e imediatas, que vão sendo relatadas pelo entrevistado de forma espontânea ao responderem às perguntas abertas, uma vez que estas foram construídas com hipóteses implícitas.

Quando se vale do uso da observação, é preciso ater-se nas particularidades desta técnica. A pesquisa com observação utiliza os sentidos para que se obtenham informações de determinados pontos em relação à realidade, que seriam imperceptíveis através das entrevistas (FARIAS FILHO; ARRUDA FILHO, 2013). Diante de variadas formas de observação, encontra-se a não participante. Nela, o observador "fica de fora da realidade a estudar. O diário de campo, também chamado de formulário, é utilizado quando o sujeito conta com a presença do pesquisador que está a registrar as informações coletadas durante a entrevista. Este pesquisador pode estar acompanhado ou não de um auxiliar (CERVO; BERVIAN; SILVA, 2007).

Após a realização da coleta de dados, a técnica aplicada foi a análise de interpretação, inserida na análise de dados qualitativos. Barros e Lehfeld (2007) explicam que o pesquisador deve registrar os dados obtidos e, após este registro, partir para o processo de classificação e categorização, onde, a partir deste momento, os dados examinados passam a ser elementos importantes para a comprovação ou não das hipóteses. Já Mascarenhas (2012) salienta que o pesquisador, ao realizar a análise de dados, deve organizar os mesmos, procurando uma maneira de lidar com estas informações de forma eficiente.

\section{RESULTADOS}

Frente aos resultados adquiridos para a presente pesquisa, os dados foram divididos de acordo com o roteiro semiestruturado atrelado aos objetivos específicos apresentados, iniciando com breve histórico sobre a instituição pública federal de ensino superior, bem como a sua comunidade em geral, 
na qual foi realizada a pesquisa de campo. A apresentação dessa instituição visa proporcionar um entendimento acerca do ambiente que originou os resultados referentes ao intraempreendedorismo.

\section{Histórico e Dados Gerais}

A instituição na qual foram realizadas as entrevistas é uma universidade federal situada em Porto Alegre e que é voltada à geração de um ensino superior de qualidade e busca contínua da excelência em ensino, pesquisa e extensão. Essa instituição almeja alcançar esse propósito por meio de práticas de ensino e aprendizagem contemporâneas, iniciativas permanentes de internacionalização, expansão do conceito de interdisciplinaridade para o conceito de multidisciplinaridade, buscando integração entre as áreas de atuação e de áreas de conhecimento.

A Universidade é constituída, de acordo com o seu estatuto, por órgãos da administração superior, do Hospital Universitário, das unidades acadêmicas (institutos, escolas e faculdades), institutos especializados e centros de estudos interdisciplinares. A instituição agrega em seu PDI (Plano de Desenvolvimento Institucional) o empreendedorismo como um fator crucial, incentivando relacionamentos que gerem a inovação e resultados sociais significativos.

Para estimular o empreendedorismo, a instituição conta com uma secretaria de desenvolvimento tecnológico, que promove a interação da Universidade com a sociedade propiciando e apoiando atividades voltadas ao desenvolvimento tecnológico e inovação. Esta secretaria oportuniza a cultura e prática do empreendedorismo através do seu Programa de Empreendedorismo, possibilitando a implementação de ações conjuntas para estimular o empreendedorismo em todas as áreas de atuação da instituição. 
Características do perfil comportamental do intraempreendedor de organizações públicas

O empreendedorismo é fator predominante dentro da Instituição e algo valorizado entre os indivíduos que compõem a Universidade, apesar de haver resistências por alguns. No período de coleta de dados, percebeu-se que as entrevistadas possuem características semelhantes no que tange ao intraempreendedorismo, mesmo ocupando posições hierárquicas distintas. A pró- atividade, persistência e empatia são qualidades predominantes entre as mesmas. A vontade de fazer algo diferente e de empreender são requisitos claros e claramente percebíveis.

O estímulo por parte das organizações para que o empreendedorismo se faça presente, é algo a ser considerado, pois deve haver a associação das características e competências pessoais do profissional com essa potencialidade às oportunidades do ambiente (LENZI et al., 2012). O fato da Universidade estar envolta em processos de empreendedorismo e inovação em seus diversos setores, acaba facilitando para que estes objetivos sejam alcançados pelas entrevistadas, uma vez que todas salientaram a importância do ambiente físico que estimula para a criatividade e inovação, apesar das limitações financeiras. Verificou-se que a Universidade dá liberdade para a inovação, principalmente em sala de aula, mas não representa que irá proporcionar recursos econômicos para este fim. No entanto, fora observado pela pesquisadora, que todas as entrevistadas valem- se de suas economias para arcar com os custos de materiais que julgam importantes para inovar frente aos seus clientes, no caso, os discentes. Dessa forma, deixam explícita a iniciativa empreendedora e intraempreendedora em fazer acontecer.

Para o Global Entrepreneurship Monitor (GEM), o empreendedorismo é categorizado por oportunidade, onde algumas 
pessoas se inserem por encontrarem um espaço de mercado ainda não explorado ou um novo negócio mesmo estando empregado e por necessidade, que por motivos voltados ao desemprego acaba por criar algo com o intuito de constituir renda para sua sobrevivência e até mesmo familiar. Em relação aos tipos de empreendedorismo categorizados as entrevistadas identificaram-se com os tipos de empreendedor quando foram questionadas sobre com qual se identificam. As Entrevistadas 1 e 2 relatam que as necessidades impulsionaram-nas para o empreendedorismo, por motivos que vão obtenção de receita até a carência de reconhecimento. Com esta visão, Dornelas (2005) explana sobre comportamento deste indivíduo que se encontra vinculado ao processo, surgindo a partir de um fato gerador ligado a fatores externos, ambientais, sociais e pessoais, proporcionando um novo negócio. No entanto, para as Entrevistadas 3 e 4, o empreendedorismo veio através da necessidade e, por consequência tornou-se uma oportunidade, onde a característica empreendedora e o reconhecimento impulsionam-nas para querer fazer mais dentro da instituição. Já para a Entrevistada 5 a oportunidade se fez presente em sua trajetória, pois, conforme aprendia, queria fazer para o próximo, ou seja, adquiria conhecimentos através de trabalhos manuais e artesanatos, fazendo deles uma geração de renda, apenas pelo fato de mostrar a sua capacidade de criar e reinventar.

Durante o período de coleta das informações para o diário de campo, observou-se que a vontade de empreender e obter este suporte dentro da instituição é algo de grande valia para todas as entrevistadas e a satisfação de exercer esta função dentro de um ambiente público é visível. Portanto, foram questionadas sobre como é ser empreendedor. E ser pró-ativo e ousado foi a resposta unânime entre as entrevistadas, o que, segundo Bessi (2016), a percepção do empreendedor que almeja vencer os obstáculos encontrados no desenvolvimento de pro- 
cessos ou de negócios concretiza os objetivos estipulados pelo mesmo. A Entrevistada 2 descreve a sua afeição pelo ofício, correlacionando- o com a vontade de ampliar os horizontes desse mundo empreendedor. A vontade de inovar, até mesmo dentro de algo já existente e as oportunidades que a Universidade proporciona aumenta o carisma e apreço por empreender, finaliza. Para a Entrevistada 4, ser empreendedor é estar se atualizando e melhorando diariamente para que os objetivos sejam alcançados, amenizando os riscos que o empreendedorismo apresenta. Esta característica vai ao encontro do ponto de vista de Morais (2013), que denomina o empreendedor como um ser dinâmico, visionário, ativo e perseverante, que busca os seus objetivos, renovando, inovando e fazendo acontecer.

Em contrapartida, a autora questiona sobre como é ser colaborador público e empreendedor onde, segundo Fontes (2014), o servidor que anseia por oportunidades possui capacidade de inovar, desafiando a gestão atual e provocando uma mudança responsável dentro da organização; oportuniza a presença e o destaque de empreendedores nos serviços públicos, impulsionando os gestores a ampliarem seus conhecimentos com a finalidade de encontrar formatos inovadores de gerenciamento. Com esta percepção, a Entrevistada 4 visualiza no colaborador público uma forma de contribuir para a sociedade, fazendo o diferente em prol de todos. No entanto, todas as entrevistadas possuem o mesmo entendimento em servir o público de forma responsável, comprometida, contribuindo para a sociedade com algo diferente e de grande valia através de ações empreendedoras.

Atributos e comportamento do intraempreendedor na gestão pública

Para Hisrich e Peters (2004), o intraempreendedorismo pode ser denominado de empreendedorismo corporativo, 
ou seja, atitudes e ações dos empreendedores dentro das organizações.

Em relação aos atributos, a questão de se fazer conhecer é predominante entre as respostas adquiridas. Ter uma resposta negativa e não se contentar com ela acaba por motivar o intraempreendedor, conforme a Entrevistada 1. Algumas das entrevistadas acreditam que a conscientização e a apresentação de projetos que culminam em resultados positivos para todos que ali exercem suas atividades pode cativar mais colaboradores no que tange à mudança. Em alguns setores, esta mudança deve ser inserida nas chefias, utilizando argumentos concretos de que estas inovações irão proporcionar o bem a todos e não individualmente, conforme a Entrevistada 3.

Lana (2010) salienta que a organização que promove o intraempreendedorismo cria possibilidades para que o colaborador se coloque como proprietário do negócio, construindo uma estrutura e um clima organizacional que propicia o desenvolvimento da inovação. A busca por algo melhor foi unânime entre as entrevistadas quando questionadas sobre o comportamento intraempreendedor. A inquietude é fator prevalecente naquele que desafia alguns obstáculos, conforme o relato da Entrevistada 5. O processo de gestão existe e não é possível quebrar as regras ali impostas, mas encontra-se alguns setores dentro da instituição que oportuniza uma liberdade para que se alcancem os resultados esperados no projeto apresentado aos gestores, bem como a importância de cada setor em ofertar esta autonomia entre os colaboradores, segundo a Entrevistada 2.

Na visão da Entrevistada 3, a importância da gestão de pessoas frente a conflitos voltados às resistências por parte de alguns servidores seria de grande relevância. A resiliência existente por parte de colaboradores mais antigos da universidade, onde as crenças imperam e o desconforto de acreditarem que

ReMAS • Revista Metodista de Administração do Sul, v. 2, N. 2, 2017 
deixarão de ser importantes dentro da instituição, tornam-se barreiras para que a inovação, oriundas do intraempreendedorismo, predomine ainda mais na organização. Ainda existem pessoas que acreditam na forma mais concreta de exercer suas funções no meio acadêmico, onde o formato tradicional de sua formação permanece sendo o mais indicado, o que acaba dificultando a inserção do novo neste segmento, mesmo com a aprovação da gestão da instituição que incentiva a inovação, finaliza. Para Pavitt, Bessant e Tidd (2008), inúmeras circunstâncias podem levar as diferentes soluções, como em organizações estatais, que necessitam reformularem-se, com o objetivo de se adequar às repercussões externas políticas e reguladoras. E, para se destacar como intraempreendedor dentro da organização, depende do perfil e das oportunidades de cada indivíduo, segundo a Entrevistada 5. O que, para Dornelas (2003), o estímulo para tentativa e erro por parte da organização permite que os funcionários conheçam e demonstrem suas ideias sem receios de retaliações por parte de seus superiores.

\section{Riscos e barreiras do empreendedorismo}

O empreendedorismo, apesar de ser considerado inovador e precursor de oportunidades, também apresenta riscos que definem a continuação dos processos a serem realizados. Segundo Seiffert (2008), esta atividade proporciona dúvidas e incertezas, por mais prática que aparente ser. O autor enfatiza que esta ocupação acaba sendo confusa devido às influências que recebe por fatores econômicos, sociais e institucionais, o que exige uma conciliação de talentos, ideias e conhecimentos. Na percepção de todas as entrevistadas, estes riscos existem, mas é preciso trabalhar para que os mesmos tornem-se os mínimos possíveis e que os resultados sejam alcançados positivamente. A questão financeira é uma ameaça considerável dentro da instituição pública, mas não a impede de executar as 
suas atividades. Em algumas situações, o inovar acabou sendo patrocinado por recursos financeiros de servidores, relata a Entrevistada 4. Mas existe o risco de aceitar o novo, por parte de outros indivíduos, conforme a Entrevistada 5. Segundo ela, as pessoas têm receio em inovar, e esta postura muitas vezes lhe gerou frustração e descontentamento, finaliza. As respostas adquiridas vêm ao encontro do que Maximiano (2011) classifica como indivíduo empreendedor. Para o autor, uma pessoa empreendedora é capaz de planejar e realizar algo novo, com características próprias se destacando frente ao concorrente com o seu talento de criação e realização.

Diante dos riscos apresentados, fora questionada, a possibilidade de desistir frente às barreiras existentes. A Entrevistada 1 relata que no início de suas atividades dentro da Instituição, a vontade de abdicar do seu cargo foi grande, quase que decisiva. Devido a sua experiência no setor privado onde o funcionamento é mais ágil, debater-se com o processo contrário, que é no serviço público, onde tudo que se queira fazer e/ou comprar abrem-se processos de licitações que levam meses para se concretizar, causou-lhe, certo desconforto e onerosidade. Mas, com o tempo, observou que acompanhar, instruir empreendedores a se destacar no mercado, analisar no que aquele dinheiro público está sendo investido e ver os bons resultados foi o que a manteve, e ainda mantém no seu trabalho. No entanto, a Entrevistada 2 nunca pensou em desistir diante das barreiras que surgem; pelo contrário, nutre um sentimento de adoração ao seu trabalho, já que muito batalhou para alcançar a sua posição dentro da Universidade e a mesma abriu muitas portas, o que a faz sentir-se totalmente realizada profissionalmente. Já a Entrevistada 5 relata que em alguns momentos teve vontade de desistir, mas a sua persistência fortaleceu-a para seguir adiante. No entanto, desistir nunca fez parte dos planos da Entrevistada 3. Para ela, a sociedade

ReMaS - Revista Metodista de Administração do Sul, v. 2, N. 2, 2017 
merece e precisa da gestão pública e, mesmo diante de todas as dificuldades encontradas neste meio, a desistência não faz parte de suas intenções, onde com seu trabalho a busca pelo melhor neste segmento será incessante, finaliza. A Entrevistada 4 relata que possui uma verba reservada no seu orçamento familiar, para ser utilizado em atividades em sala de aula, por exemplo. E, diante desta limitação orçamentária que presencia no ambiente público, não deixa de executar as suas atividades, nunca desistindo do seu ideal dentro da instituição.

Percepção de intraempreendedores a respeito da gestão pública

A organização pública é envolta por seguimentos consolidados desde administração pública burocrática e ações empreendedoras neste segmento acabam por demonstrar certa adversidade ao que se apresenta. Para Dornelas (2005), as ações e o comportamento do empreendedor estão vinculados ao processo que surge a partir de um fato gerador atrelados ao um conjunto fatores externos, ambientais, sociais e pessoais, viabilizando o início de um novo negócio e/ou processos. As entrevistadas são instigadas pela autora sobre a postura como gestor de uma organização pública frente às ações empreendedoras que se instalam na instituição. A busca pela conscientização teria como ponto de partida as pessoas, segundo a Entrevistada 1. O empreendedorismo e a inovação vêm das pessoas sempre e não de processos. Então, é necessário mobilizá-las para fazer o melhor. Já para a Entrevistada 2, a Universidade é empreendedora em alguns pontos e em outros menos, devido a burocracia que existe, tendo maior dificuldade em inserir a questão empreendedorismo e inovação. É necessário haver mudanças de paradigmas, assim como no sistema pedagógico tradicional, considerado engessado. A mesma conclui que a flexibilidade para haver estas mudanças iria facilitar nas melhorias. Os relatos supracitados condizem 
com Chiavenato (2003) que explica onde há conflitos e dilemas organizacionais pode originar receios tanto positivos e negativos, mas, com a solução dessas particularidades, a organização é levada à inovação e à mudança.

Para a Entrevistada 5, mesmo em posição de gestora, percebeu que não é possível fazer tudo em uma única vez. É preciso começar, através de pequenas ações, entendendo os diferentes processos de funcionamento administrativos, além de trabalhar em questões internas entre os colaboradores, observando suas atribuições e aflições diante de algumas situações e a partir de então, traçar um plano de ação para fazer diferente e melhor. A busca por líderes seria um dos pontos iniciais a ser realizado pela Entrevistada 3 em cargo de gestor da instituição pública. Após escolha dos líderes, sob critério de nível técnico e com o perfil apropriado com a inovação, trabalharia de forma conjunta para que os servidores se sentissem protagonistas das mudanças propostas, e não apenas individualmente. A entrevistada salienta a importância da colaboração e da forma interdisciplinar de se exercer as atividades funcionais do dia a dia. Com o mesmo perfil de gestão, a autora observou na Entrevistada 4, que exemplificou a sua maneira de exercer as suas atividades, caso fosse gestora. Através de reuniões individuais com os servidores, tentaria perceber quais seriam as disposições e as necessidades existentes, já que acredita que o medo faz com que as pessoas acreditem que não possuem o perfil intraempreendedor. A entrevistada salienta que o empreendedorismo pode ser despertado, mas tem que ter ferramentas onde o mínimo que fizer diferente fará a diferença mais adiante.

Para Torres (2004), o modelo burocrático não foi adotado em sua totalidade no Brasil, pois ainda é administrado através de métodos que desconhecem ou desprezam os princípios da impessoalidade, publicidade, especialização, profissionalismo, 
entre outros. Como, em organizações privadas, as divergências também se fazem presente em organizações públicas o que acaba tornando alguns processos custosos em sua resolução. Quando questionado sobre a existência de conflitos, a Entrevistada 1 relata que há troca de conhecimentos entre as organizações públicas e privadas através de reuniões mensais onde são debatidas as informações sobre o que está ocorrendo nas dependências dos setores, ou seja, quase não há discordâncias. No entanto, sabe-se que tem algumas demandas que devem ser abraçadas, principalmente quando estas vêm da direção da Universidade, mas tem que estar sempre se flexibilizando e renovando, afirma a Entrevistada 2. Já a Entrevistada 5 relata que, apesar dos trâmites e do processo moroso, pode haver apoio da direção e reitoria, mas não se pode forçar os docentes da Universidade. Em certos momentos, a revolta transparece, pois as pessoas referem-se ao empreendedorismo como modismo, em fazer as coisas diferentes. A Universidade trabalha em prol do empreendedorismo; os diretores apoiam esta ideia, mas ainda assim existe muito conservadorismo. A entrevistada conclui que não é fácil convencer pessoas que, amparados pelo regimento da instabilidade, não querem sair da sua zona de conforto.

O nervosismo faz-se presente, declara a Entrevistada 3. A mesma vale-se do questionamento argumentando sempre que possível. Muitas vezes abandonou alguns projetos por não ter respaldo e reconhecimento. Mesmo frente aos empecilhos, a Universidade é bastante inovadora e aberta, conclui a entrevistada. E, por fim, a Entrevistada 4 posiciona-se de forma individual em relação aos conflitos existentes. Declara que as suas atividades dentro da Universidade são realizadas somente pela mesma, sem depender de outrem, o que classifica como sendo escolha de cada um. O empreendedorismo é uma competência necessária dentro da Instituição. Mas, quando 
observa que não está sendo aceita entre os demais, não tenta a convencê-la do contrário, pois acredita que deve ser natural de cada indivíduo, finaliza.

Incentivos e barreiras à inovação e ao empreendedorismo na gestão pública

A organização que estimula o intraempreendedorismo procura criar condições para que o colaborador se coloque-se como gestor de uma empresa, construindo uma estrutura e um clima organizacional que adote e conceda o desenvolvimento da inovação (LANA, 2010). Diante deste conceito, esta questão foi abordada entre as entrevistadas, onde as mesmas relatam que este quesito está sendo mais amparado dentro da gestão pública há alguns anos. Para a Entrevistada 1 a gestão pública não está mais fechada para a inovação, pois acredita que as ações realizadas através do empreendedorismo podem proporcionar algo novo que será implementado mesmo diante das limitações que há dentro da esfera pública, mas ainda assim, o empreendedor possui o talento de reverter estas barreiras a seu favor, contornando a situação, o que denomina como batalhador. Acredita também que a comunicação é um dos fatores importantes para a propagação da inovação dentro da Instituição.

Já para a Entrevistada 5, a inovação na gestão pública vai depender do perfil e do comportamento de cada setor/gestor/ colaborador. Mas, quando uma decisão é tomada, ela precisa ser diferente, em formato inovador. Enfatiza a dificuldade em ter esta atitude sem pensar em empreender ou intraempreender. A entrevistada ressalta que nem sempre a adesão por parte dos colaboradores que participarão destas mudanças irá ocorrer, sendo este o ônus do processo. Este entendimento vem ao encontro dos fundamentos que estimula as inovações, através da ação do empreendedor corporativo conforme

ReMAS - Revista Metodista de Administração do Sul, v. 2, N. 2, 2017 
Ferras et.al. (2014), onde enfatizam que, para a inovação ser eficiente dentro da empresa, a cultura deve estar adequada; do contrário, não desenvolverá produtos e serviços novos. As pessoas precisam ser sensibilizadas, mesmo que a instituição pública acredite que a inovação não irá acontecer, o que será o contrário, pois haverá uma propagação entre pequenos grupos. Mas tem que haver uma liderança e indivíduos que queiram fazer acontecer, apresentar argumentos baseados em outras organizações, mostrando que é possível inovar dentro do ambiente público. No entanto, a inovação se faz pelo comprometimento, de olhar sistêmico e de relacionamentos para então conseguir articular recursos aptos para que a inovação dentro da gestão pública seja ampliada e amparada por todos, conclui a Entrevistada 3.

A inovação está dentro de cada pessoa e que esta deve buscar algo diferente para fazer melhor, podendo ser implementado dentro de uma organização pública, enfatiza a Entrevistada 4. Esta visão coincide com Albagli e Lastres (1999) que descrevem a inovação como atributos distintos que dependem de cada indivíduo e da sua forma de encarar novos conhecimentos, lidar com fontes de inovação diversas e dos ambientes em que se inserem, bem como com o nível de entendimento incógnito presente nesses lugares. Apesar da Instituição de ensino público oportunizar uma liberdade para que se inove na educação dos seus alunos/clientes, a inovação ainda é considerada de baixa aprovação entre alguns colaboradores, apesar de todo o esforço por parte da universidade. Para a Entrevistada 5, este é um processo de aceitação entre todos os funcionários e, mesmo em posição de superioridade hierárquica, ressalta que não tem como exigir que todos inovem, pois não é uma cultura generalizada, ainda é um processo de aprovação. 
Inovação organizacional na gestão pública

A inovação e seus tipos foram citadas durante a entrevista, e assim obter informações sobre a inovação radical e burocrática e qual seria a mais apropriada para que houvesse mudanças neste setor, considerado fechado e ultrapassado pela sociedade. Souza (2009) refere-se à inovação radical como uma ruptura de modelos, onde a mudança exorbitante num produto ou processo torna-se mais difícil. Para a Entrevistada 2 , a inovação radical não seria o mais apropriado. Acredita que as mudanças podem ser inseridas aos poucos e melhorando gradativamente. Segundo ela, a instituição vem propiciando aos seus colaboradores um feedback para que se façam melhorias entre a comunidade da Universidade. Já a Entrevistada 1 relata que a burocracia é necessária, dependendo da forma como é utilizada. O grande problema são as pessoas que utilizam e trabalham com ela. Dentro da Universidade Federal a inovação incremental faz-se presente, sendo difícil o uso da inovação radical explana a Entrevistada 5. Em contrapartida, criar uma nova cultura e com a entrada de novos servidores qualificados, acaba proporcionando mais inovação para as instituições públicas em geral, segundo a Entrevistada 3.

A inovação é algo que perpetua na Instituição estudada, sendo esta uma organização pública federal. Segundo Albagli e Lastres (1999), a inovação é uma mistura de diferente atributos e fontes que dependem de cada agente e da sua forma em lidar com os novos conhecimentos, tal como o grau de entendimento oculto existente nos ambientes que estão inseridos. Já para Lima et al. (2014), as organizações precisam se adaptar para que as inovações sejam bem administradas, mensurando o nível de desempenho, o planejamento, as carências, para então se destacar frente ao mercado competitivo. Baseada nestas peculiaridades, a questão referente ao inovar dentro de ambiente público consolidado e com diretrizes consideradas obsoletas

ReMas - Revista Metodista de Administração do Sul, v. 2, N. 2, 2017 
foi levantada. A Entrevistada 1 acredita que a inovação é capaz de fazer algo diferente sem se desfazer das leis, já que o serviço público é regido por elas. Não se pode alterá-las, mas é possível executar as tarefas com os processos e as ações a serem realizadas, sendo estas inovadoras, finaliza a entrevistada. A inovação é vista pelos colaboradores da secretaria de desenvolvimento tecnológico da Instituição como algo que permeia tudo, explica a Entrevistada 2. O planejamento deste setor é baseado no preceito da inovação, uma vez que o empreendedorismo necessita de planejamento e, ao apresentar os resultados para a Instituição é necessário planejar, completa.

No entanto, é necessário que haja mais investimentos por parte gestão da Universidade referente à mão de obra indireta que existe dentro da Instituição, como os bolsistas, por exemplo, apresentando resultados indiretos, criando e valorizando as atividades desenvolvidas por estes intraempreendedores indiretos, justifica a Entrevistada 3.

No próximo capítulo, serão apresentadas as considerações finais do referente estudo, apresentando a resposta da principal abordagem.

\section{CONSIDERAÇÕES FINAIS}

A partir da pergunta central elaborou-se, três objetivos foram estipulados como forma de atingir o resultado. Foi realizada uma pesquisa em literaturas especializadas sobre o assunto. Esta busca ocorreu antes da aplicação das entrevistas e observação não participante, baseadas nos procedimentos metodológicos definidos em relação ao formato a ser realizado, fazendo com que os objetivos fossem cumpridos. O primeiro dos objetivos específicos foi a identificação do perfil comportamental do intraempreendedor de organizações públicas. Diante das limitações encontradas na teoria, pode-se verificar que o comportamento do intraempreende- 
dor é existente dentro da instituição. O diário de campo e as entrevistas executadas mostraram que a teoria explana o intraempreendedor tal como se encontra na Universidade. As características exemplificadas por alguns autores conferem ao que se encontra na Instituição. Em relação a este assunto, os mesmos ressaltam a importância deste empreendedor corporativo, além do ambiente que deve ser propício para novas criações, comprometimento da gestão e mudanças culturais, onde esta última encontra-se em fase de aceitação por parte de alguns colaboradores que mantêm a sua visão voltada ao conservadorismo, sem aberturas para o novo. Para os colaboradores, os sistemas burocráticos e financeiros existem, mas que no momento não podem ser mudados, e estar preparado para efetuar suas atividades inovadoras diante dos limites impostos e assumir os riscos são características natas do intraempreendedor.

No segundo objetivo, a intenção foi verificar a percepção de intraempreendedores a respeito da gestão pública. $\mathrm{Na}$ Universidade existem setores voltados ao empreendedorismo e, por conseguinte, seus servidores tornam-se intraempreendedores, auxiliando e contribuindo para um ensino acadêmico inovador, ofertando aos discentes oportunidades de empreender na sua formação e fazer diferente no mercado e na sociedade. Mesmo com toda esta modernidade dentro de um ambiente organizacional público, os intraempreendedores deparam-se com limitações provenientes da gestão pública como um todo. Apesar da Universidade propiciar liberdade no que tange ao empreendedorismo e a inovação fazendo dela uma peça importante no ensino acadêmico, existem fatores burocráticos e financeiros que dificultam o fluxo dos eventos gerados pelo intraempreendedor que ali executa suas funções, demonstrando que a teoria referente à gestão pública converge com o que a entrevista mostrou. 
E, por fim, o último objetivo apresentado foi o relato dos incentivos e as barreiras à inovação e ao empreendedorismo dentro da gestão pública, na visão de intraempreendedores. A intenção foi trazer a experiência dos intraempreendedores que ali executam suas funções e como esta vem sendo incentivada, bem como, os obstáculos encontrados para que o empreendedorismo e a inovação transcorram. De acordo com o levantamento teórico, a realidade vivida dentro da Universidade condiz com a teoria. Existe o apoio necessário de acordo com cada ação voltada à inovação e ao empreendedorismo dentro da Instituição. As barreiras encontradas estão envoltas no sistema burocrático regido pelas leis da gestão pública, além dos custeios financeiros por parte da organização que dificultam a execução imediata das ações propostas pelos intraempreendedores, mas estes impedimentos não impedem o cumprimento dos projetos elaborados, por parte do empreendedor colaborativo, a serem executados na instituição. Em relatos adquiridos nas entrevistas, em variadas situações fora preciso arcar com recursos financeiros particulares às atividades acadêmicas, bem como eventos voltados para o empreendedorismo, com a finalidade de trazer a inovação para o desenvolvimento de suas atividades, o que não as fazem desistir dos ideais em relação ao que está sendo proposto.

Com base nos dados levantados para atender aos objetivos específicos, bem como ao objetivo geral, foi possível responder a pergunta de pesquisa, que é dado pela sentença: Quais os efeitos gerados da atuação de intraempreendedores em uma organização pública?

É visível as características do intraempreendedor, são consideradas peças-chave para se fazer presentes nas organizações públicas. As descrições dos efeitos gerados em uma organização que caracterizam a atuação de intraempreendedores foram descritos de acordo com a pesquisa realizada. 
Procurou-se entender a existência e a importância do intraempreendedor dentro de uma organização pública conhecida por seu regimento interno fechado e avesso à inovação, e quanto ao perfil destes colaboradores, atrelados ao empreendedorismo priorizado pela instituição. Segundo os resultados da pesquisa, foi possível fazer a identificação do perfil intraempreendedor e o seu valor nos processos inovadores voltados à educação dentro da Universidade, uma vez que as suas ações devem estar ligadas ao Plano de Desenvolvimento Institucional (PDI) que tem o empreendedorismo como fator de grande importância. Percebeu-se a vontade de empreender, tal como o fascínio pelo tema em todas as entrevistadas. Ser inovador é elemento fundamental para que haja mudanças organizacionais. Reconhecer o colaborador interno projeta em maior valorização por parte da sociedade, desacreditada das competências oriundas das organizações públicas. Por possuírem características intraempreendedores, as servidoras da Universidade provêm de capacidade em tornar um projeto realidade, além de transformar o que está na teoria em prática.

O fato de não temerem os riscos acaba por impulsionar ainda mais o desenvolvimento de suas ideias. O empreendedorismo é composto de inovação e, conforme apresentado nesta pesquisa, inovar faz parte dos atributos das colaboradoras. No referencial teórico deste trabalho são trazidos conceitos acerca do empreendedorismo, inovação e do perfil do intraempreendedor, assim como a gestão pública e suas vertentes. $\mathrm{O}$ ponto de maior relevância foi o perfil do intraempreendedor em contrapartida aos impedimentos que uma organização pública propicia. Além de se deparar com um ambiente onde o empreendedorismo faz parte do seu dia a dia, a Universidade favorece aos seus colaboradores meios de inovar com o objetivo de formar discentes voltados às mudanças significativas e com destaque no mercado de trabalho. A Universidade 
oferece secretarias com atividades de cunho empreendedor e núcleos apontados para a inovação voltados aos docentes e à comunidade acadêmica em geral. O presente trabalho teve, essencialmente, dois limites à pesquisa. O primeiro diz respeito à característica metodológica de ser um trabalho qualitativo. Em outras palavras, isso significa que as evidências apontadas se referem-se à percepção única e exclusiva das entrevistadas, não podendo ser generalizado para todos os profissionais de serviços públicos que possam se enquadrar no perfil de intraempreendedor. $\mathrm{O}$ segundo limite à pesquisa realizada foi a dificuldade de identificar pessoas com perfil intraempreendedor, se for feita uma comparação com a iniciativa privada.

Foi possível perceber que o empreendedorismo pode fazer parte de uma organização pública e que a participação do intraempreendedor é de grande relevância. A pesquisadora sugere fontes de estudos como a identificação desses perfis empreendedores em outros segmentos públicos, como prefeituras e governos, e assim, identificar as causas e barreiras que podem ser rompidas para que serviços de necessidades básicas para a população possam ser melhorados, além de apresentar as ações executadas por estes servidores no viés do empreendedorismo corporativo, caso houver. Elaborar uma investigação acadêmica, bem como, realizar uma pesquisa quantitativa, pode estimular colaboradores e gestores, gerando mais adeptos ao empreendedorismo em órgãos públicos. A sugestão de pergunta para o estudo seria: Como é possível reconhecer o intraempreendedor através de serviços de necessidades básicas para a população na esfera pública municipal? Esse pode ser o ponto de partida para que mudanças possam ser efetuadas através de iniciativas simples e com mão de obra inclusa, podendo ter um saldo positivo em áreas com déficit considerável no que tange atendimento e desenvolvimento nos serviços ofertados para a sociedade, que clama por dig- 
nidade e melhorias dignas em tudo que contribui através dos impostos, pago por todos.

\section{REFERÊNCIAS}

ABRANTES, José. Teoria Geral da Administração: a antropologia empresarial e a problemática ambiental. Rio de Janeiro: Interciência, 2012. Disponível em: http://metodistaportoalegre.bv3.digitalpages.com.br/users/ publications/9788571932975/pages/-17. Acesso em: 08 maio 2017.

ALBAGLI, Sarita; LASTRES, Helena. Informação e globalização na era do conhecimento. Rio de Janeiro: Campus, 1999.

AMORIM, Sônia Naves David. Ética na esfera pública: a busca de novas relações Estado/ Sociedade. Revista do Serviço Público, v. 2, p. 94-104, 2000. Disponível em: <https://revista.enap.gov.br/index.php/RSP/article/ view/327/333>. Acesso em: 25 abr. 2017.

ASIMOV, Isaac. Cronologia das ciências e das descobertas. Rio de Janeiro: Civilização Brasileira, 1993.

BARON, A. Robert; SHANE, A. Scott. Empreendedorismo: uma visão do processo. São Paulo: Thomson Learning, 2007.

BARROS, Aidil Jesus da Silveira; LEHFELD, Neide Aparecida de Souza. Fundamentos da Metodologia Científica. 3. ed. São Paulo: Pearson Prentice Hall, 2007. Disponível em: <http://metodistaportoalegre.bv3.digitalpages.com. br/users/publications/9788576051565/pages/_1>. Acesso em: 17 nov. 2016.

BESSI, Vânia Gisele. Empreendedorismo: ação empreendedora. São Leopoldo: Trajetos Editoriais, 2016.

BRASIL. Ministério do Planejamento, Orçamento e Gestão. Secretaria de Gestão. Gestão Pública Empreendedora. Brasília, 2000. Disponível em: http://www.dominiopublico.gov.br/download/texto/p1000027.pdf. Acesso em: 24 maio 2017.

BRESSER - PEREIRA, Luiz Carlos. A reforma gerencial do Estado de 1995. Revista de Administração Pública, v. 34, p. 7-26, 2000. Disponível em: http://www.bresserpereira.org.br/papers/2000/81RefGerenc1995-INA.pdf. Acesso em: 25 ab. 2017.

CERVO, Luiz Amado; BERVIAN, Pedro Alcino; SILVA, Roberto da. Metodologia Científica. 6. ed. São Paulo: Pearson Prentice Hall, 2007. Disponível em: <http://metodistaportoalegre.bv3.digitalpages.com.br/users/publications/9788576050476/pages/_5>. Acesso em: 7 jun. 2017. 
CHIAVENATO, Idalberto. Introdução à teoria clássica da administração: uma visão abrangente da moderna administração das organizações. 7. ed. Rio de Janeiro: Elsevier, 2003.

DIEHL, Astor Antônio; TATIM, Denise Carvalho. Pesquisa em Ciências Sociais Aplicadas: métodos e técnicas. São Paulo: Prentice Hall, 2004. Disponível em: <http://metodistaportoalegre.bv3.digitalpages.com.br/users/ publications/9788587918949/pages/_1>. Acesso em: 17 nov. 2016.

DORNELAS, José Carlos Assis. Empreendedorismo na Prática: mitos e verdades do empreendedor de sucesso. Rio de Janeiro: Elsevier, 2007.

DORNELAS, José Carlos Assis. Empreendedorismo: transformando ideias em negócios. 2. ed. Rio de Janeiro: Elsevier, 2005.

DORNELAS, José Carlos Assis. Empreendedorismo Corporativo. Como ser empreendedor, inovar e se diferenciar na sua empresa. São Paulo: Campus, 2003.

DOLABELA, Fernando. O Segredo de Luísa. São Paulo: Cultura, 2003.

DRUCKER, Peter F. Inovação e Espírito Empreendedor (entrepreneurship): práticas e princípios. São Paulo: Pioneira Thomson Learning, 2005.

FARIAS FILHO, Milton Cordeiro; ARRUDA FILHO, Emílio. Planejamento da Pesquisa Científica. São Paulo: Atlas, 2013.

FEGER, J. E.; FISCHER, A.; NODARI, T. M. Características empreendedoras de gestores públicos municipais: uma análise comparativa entre secretários e servidores. RACE, Unoesc, v. 8, n. 2, p. 215- 238, jul./dez. 2009. Disponível em: <http://editora.unoesc.edu.br/index.php/race/article/view/276/pdf_28>. Acesso em: 10 agosto 2017.

FERRAS, Robson Paulo Ribeiro et al. Empreendedorismo Corporativo em Organizações Públicas: um estudo em uma universidade pública. XXXVIII Encontro da ANPAD, 2014. Anais... Rio de Janeiro: RJ, 2014. Disponível em: <http://www.anpad.org.br/admin/pdf/2014_EnANPAD_APB275.pdf>. Acesso em: 07 abr. 2017.

FONTES, Vanielly. Empreendedorismo na gestão pública. Brasília: Conselho Federal de Administração, 2014. Disponível em: <http://www.cfa.org.br/ acoes-cfa/artigos/usuarios/empreendedorismo-na-gestao-publica>. Acesso em: 25 maio 2017.

FLICK, Uwe. Introdução a Pesquisa Qualitativa. 3 ed. Porto Alegre: Artmed, 2009.

GLOBAL ENTREPRENEURSHIP MONITOR (GEM). Empreendedorismo no Brasil. Curitiba: IBQP, 2015. Disponível em: <http://www.bibliotecas.sebrae. 
com.br/chronus/ARQUIVOS_CHRONUS/bds/bds.nsf/4826171de33895ae2aa12cafe998c0a5/\$File/7347.pdf>. Acesso: 10 abr. 2017.

HAIR JR, Joseph F. et al. Fundamentos de Pesquisa em Administração. Porto Alegre: Bookman, 2005.

HISRICH, Robert D.; PETERS, Michael P.; SHEPHERD, Dean A. Empreendedorismo. 7. ed. Porto Alegre: Bookman, 2009.

HISRICH, Robert D.; PETERS, Michael P. Empreendedorismo. 5. ed. Porto Alegre: Bookman, 2004.

HISRICH, Robert D.; PETERS, Michael P. Entrepreneurship: starting, developing, and managing a new enterprise. 2. ed. Boston: IRWIN, 1992.

JONES, Gareth R. Teoria das Organizações. São Paulo: Pearson Education do Brasil, 2010. Disponível em: <http://metodistaportoalegre.bv3.digitalpages. com.br/users/publications/9788576055600/pages/_1>. Acesso em: 10 out. 2016.

LANA, Bruno Maia Heringer. Intraempreendedorismo: uma análise das percepções do gestor sobre o perfil de seus funcionários. 2010. $101 \mathrm{f}$. Tese (Mestrado) - Universidade FUMEC, Belo Horizonte, 2010. Disponível em: $<$ http://www.fumec.br/anexos/cursos/mestrado/dissertacoes/completa/bruno_maia_heringer.pdf $>$. Acesso em: 24 mar. 2017.

LENZI, Fernando Cesar et al. Talentos Inovadores na Empresa: como identificar e desenvolver empreendedores corporativos. Curitiba: InterSaberes, 2012. Disponível em: <http://metodistaportoalegre.bv3.digitalpages.com.br/ users/publications/9788582123973/pages/-2>. Acesso em: 08 abr. 2017.

LENZI, Fernando Cesar. Os empreendedores corporativos nas empresas de grande porte dos setores mecânico, metalúrgico e de material elétrico/ comunicação em Santa Catarina: um estudo da associação entre tipos psicológicos e competências empreendedoras reconhecidas. 2008. 126 f. Tese (Doutorado) - Faculdade de Economia, Administração e Contabilidade. São Paulo, 2008. Disponível em: <http://www.teses.usp.br/teses/disponiveis/12/12139/tde-15012009-105920/pt-br.php>. Acesso em: 07 abr. 2017.

LIMA, Telma Lúcia de Andrade; MACEDO, Gleógenes Andrade; MOURA, Izabel Cristina Barros de. Influência do grau de desenvolvimento da organização sobre o grau de inovação nas empresas de pequeno porte. Exacta. EP, São Paulo, v. 12, n. 3, p. 367-375, 2014. Disponível em: <http://www.redalyc. org/articulo.oa?id=81037788011>. Acesso em: 14 out. 2016.

MARCONI, Marina de Andrade; LAKATOS, Eva Maria. Fundamentos de metodologia científica. 7. ed. São Paulo: Atlas, 2010. 
MASCARENHAS, Sidnei Augusto. Metodologia Científica. São Paulo: Pearson Education do Brasil, 2012. Disponível em: <http://metodistaportoalegre.bv3.digitalpages.com.br/users/publications/9788564574595/pages/-12>. Acesso em: 22 maio 2017.

MATTOS, Fernando; GASTAL, Cláudio; RANK, Liliane; EMEDIATO, Gustavo; OSORIO, Héctor Hérman González. Manual de Inovação. Brasília: Movimento Brasil Competitivo, 2008.

MAXIMIANO, Antonio Cesar Amaru. Administração para empreendedores: fundamentos da criação e da gestão de novos negócios. 2. ed. São Paulo: Pearson Prentice Hall, 2011.

MAZZOTTI, Alda Judith Alves; GEWANDSZNAJDER, Fernando. O método nas ciências naturais e sociais: pesquisa quantitativa e qualitativa. 2 . ed. São Paulo: Pioneira Thomson Learning, 2001.

MONTEIRO JR, João G. Criatividade e Inovação. São Paulo: Pearson Prentice Hall, 2011. Disponível em: <http://metodistaportoalegre.bv3.digitalpages.com. br/users/publications/9788576058847/pages/_1>. Acesso em: 20 maio 2017.

MORAIS, Roberto Souza de. O profissional do Futuro: uma visão empreendedora. São Paulo: Manole, 2013.

PALUDO, Augustinho. Administração Pública. 3. ed. Rio de Janeiro: Elsevier, 2013.

ROCHA NETO, Inácio. Ciência, Tecnologia \& Inovação: enunciados e reflexões. Brasília: Universa, 2004.

SANTOS, David Ferreira Lopes. A influência da inovação no desempenho das firmas no Brasil. 2009. 315 f. Tese (Doutorado) - Universidade Presbiteriana Mackenzie, São Paulo, 2009. Disponível em: <http//tede.mackenzie. br/jspui/bitstream/tede/794/1/Ullisses\%20Kazumi\%20Shimizu.pdf>. Acesso em: 09 set. 2016.

SARKAR, Soumodip. O empreendedor inovador: faça diferente e conquiste seu espaço no mercado. Rio de Janeiro: Elsevier, 2008.

SEIFFERT, Peter Quadros. Empreendendo Novos Negócios em Corporações: estratégias, processos e melhores práticas. 2. ed. São Paulo: Atlas, 2008.

SELMAN, Jim. Liderança. São Paulo: Pearson Prentice Hall, 2010. Disponível em: <http://metodistaportoalegre.bv3.digitalpages.com.br/users/publications/9788576054078/pages/-14>. Acesso em: 17 out. 2016.

SILVA, Adival do Carmo. Evolução da administração pública no Brasil e tendências de novos modelos organizacionais. 2013. 9 f. Artigo (Pós Gra- 
duação) - Instituto Cuiabano de Educação - Pós Graduação, Cuiabá, 2013. Disponível em: <http://www.ice.edu.br/TNX/storage/webdisco/2013/12/13/ outros/27b4d512efbac7d37520bc37aa78cac1.pdf $>$. Acesso em: 24 mar. 2017.

SIMANTOB, Moysés; LIPPI, Roberta. Guia Valor Econômico de Inovação nas Empresas. São Paulo: Globo, 2003.

SOUZA, Maria Cristina de Andrade. Crescimento econômico, inovação e empreendedorismo. 2009. 155 f. Tese (Mestrado) - Faculdade de Ciências Econômicas da UFRGS, Porto Alegre, 2009. Disponível em: <http://www. lume.ufrgs.br/bitstream/handle/10183/18843/000729117.pdf? sequence $=>$. Acesso em: 16 abr. 2017.

SCHUMPETER, Joseph. Capitalism, socioalism and democracy. 3. ed. New York: Harper \& Row, 1950.

TIDD, Joe; BESSANT, John; PAVITT, Keith. Gestão da inovação. 3. ed. Porto Alegre: Bookman, 2008.

TORRES, Marcelo Douglas de Figueiredo. Estado, democracia e Administração Pública no Brasil. Rio de Janeiro: FGV, 2004. 